\title{
Dikkat Eksikliği ve Dürtüselliğin Gelişmeleri Kaçırma Korkusu Arasındaki İlişkinin Yaş, Cinsiyet ve Sigara Bağımlıığı Açısından İncelenmesi
}

\section{Investigation of The Association of The Fear of Missing Out with Attention Deficit and Impulsivity in Terms of Age, Gender, and Tobacco Dependence}

\author{
${ }^{1}$ Hüseyin ÜNÜBOL, ${ }^{1}$ Gokben HIZLI SAYAR \\ ${ }^{1}$ Psychology, Uskudar University, Istanbul, Turkey
}

Hüseyin Ünübol : https://orcid.org/0000-0003-4404-6062

Gokben Hizlı Sayar: https://orcid.org/0000-0002-2514-5682

\begin{abstract}
ÖZ
Amaç: Çalışma, gelişmeleri kaçrıma korkusunun, cinsiyet, yaş ve tütün bağgmlılığı açısından dikkat eksikliğihiperaktivite ve dürtüsellik semptomlarıyla olan ilişkisini incelemeyi amaçlamıştır.

Materyal ve Metot: Çalışma örneği toplam 732 kişiden oluşmaktadır. Katılımcıların 425'i kadın, 307'si erkekti. Çalışma örnekleminde 258 sigara içen ve 474 sigara içmeyen kişi vardı. Katılımcılara bir sosyodemografik anket, Yetişkin Dikkat Eksikliği Hiperaktivite Bozukluğu Öz-Rapor Ölçeği (ASRS), Barratt Dürtüsellik Ölçeği (BIS -11) ve Üsküdar Fomo Ölçeği uygulanmıştır. Cinsiyet, yaş ve sigara içme durumu arasındaki farklılıkları test etmek için Mann Whitney U testi kullanıldı. Ölçekler arasındaki ilişkiyi incelemek için Spearman korelasyon analizi ve doğrusal regresyon analizi yapıldı.

Bulgular: Gelişmeleri Kaçırma korkusunun yoğunluğu cinsiyet veya sigara içme durumu ilişkili değilken, yaş açısından anlamlı fark vardı. Regresyon analizinde yaş, cinsiyet, sigara içme durumu, dikkat eksikliği ve dürtüsellik özelliklerini değerlendiren modelin istatistiksel olarak anlamlı olduğu bulundu. Verilerin analizi gelişmeleri kaçırma korkusu şiddetinin dikkat eksikliği ve hiperaktivite skorlarıyla arttı̆̆ 1 ancak yaşla birlikte azaldığını ortaya koydu.

Sonuç: Çalışma sonuçları, dikkat eksikliği hiperaktivitesinin özellikleri konusunda eksiklik korkusu ile doğrusal bir ilişki olduğunu göstermiştir.

Anahtar Kelimeler: Bağımlılık, dikkat eksikliği, hiperaktivite bozukluğu, dürtüsellik, sigara
\end{abstract}

\begin{abstract}
Objective: The study aimed to examine the association of the fear of missing out (FoMO) on the symptoms of attention deficit-hyperactivity and impulsivity in terms of gender, age, and tobacco dependence.

Materials and Methods: The study sample consisted of a total of 732 individuals. Of the participants, 425 were females and 307 were males. There were 258 smokers and 474 non-smokers in the study sample. Participants were administered a Socio-demographic Questionnaire, The Adult Attention Deficit Hyperactivity Disorder SelfReport Scale (ASRS), The Barratt Impulsiveness Scale (BIS-11), and Üsküdar FoMO Scale to collect data. The Mann Whitney U test was used to test the differences in terms of gender, age, and smoking status. Spearman correlation analysis and a linear regression analysis were performed to examine the correlation between the scales.

Results: The intensity of the FoMO was not variable in regard to gender or smoking status. There was a significant difference in terms of the age variable. The model in the regression analysis, which evaluated the features of age, gender, smoking status, attention deficit, and impulsivity was found out to be statistically significant.

Conclusions: The analysis of the data revealed that severity of the FoMO was increased with ASRS scores and decreased with age.

Keywords: Addictive Behavior, Attention Deficit Disorder with Hyperactivity, Impulsive Behavior, Smokers
\end{abstract}

\author{
Sorumlu Yazar / Corresponding Author: \\ Hüseyin Ünübol \\ manı 4/13, Istanbul/Turkey \\ Phone: +0905554911183 \\ Fax: +902164741256 \\ E- Mail: huseyin.unubol@uskudar.edu.tr
}

Yayın Bilgisi / Article Info:

Gönderi Tarihi/ Received: 31/05/2019

19 Mayis Mahallesi Bayar Caddesi Mehpare Sokak Demirkol Apart- Kabul Tarihi/ Accepted: 09/05./20120

Online Yayın Tarihi/ Published: 30/06/2020

Atıf/ Cited: Unubol H, Hizlı Sayar G. Investigation of The Association of The Fear of Missing Out with Attention Deficit and impulsivity in Terms of Age, Gender, and Tobacco Dependence. Online Türk Sağllk Bilimleri Dergisi 2020;5(2):260-270. doi: 2020-06-02 14:03:34 


\section{INTRODUCTION}

With the technological advances over the past 20 years, the increasingly widespread use of online communication has increased concerns about the potentially harmful effects of the social media, which may develop due to its high psychological impact and the frequency of its use. ${ }^{1}$ The increasing number of social media users, ${ }^{2}$ which suffer from the excessive use referred to internet communication disorder. Researchers have also argued that social media platforms might create a new environment as a stressor. $^{3}$

One of the effects of social media networks was introduced as the "Fear of Missing Out" (FoMO) in the literature. FoMO is a pervasive anxiety experienced in association with being absent from any rewarding experiences, which is enjoyed by others. The individuals, who worry about being missed out socially, are in a continuous search for staying in touch with others and being updated about the activities that others have experienced. ${ }^{4}$ Przybylski et al. ${ }^{4}$ argue that failures in psychological satisfaction may predict the development of the fear of missing out. As the attempts for gaining a social status gradually increases especially during adolescence, it is quite natural for the adolescents to use the social media platforms for this purpose today. An increased intensity of use of these platforms at the earlier ages may lead to developing habits and comparing oneself with the others due to the rich content and opportunities provided by the social media. ${ }^{3}$

Some studies have examined the relationships between attention components related to social media addiction. It has been shown that the intensity of FoMO can be reduced by involving in some leisure activities and that the presence of scheduled activities. ${ }^{5}$ A study by Rosen et al. demonstrated that the individuals more commonly suffering from the harmful effects of the social media use were inclined to perform multi-task assignments. ${ }^{6}$ The relationship between sustaining and controlling attention and social media addiction needs to be further considered. The longest study to date about the attention deficit and hyperactivity disorder (ADHD) noted that nicotine dependence and substance abuse were remarkably at higher levels compared to the normal population in the adults who had been followed-up since childhood. ${ }^{7}$ They also observed that highscores in the hyperactivity-impulsivity subscales of the ASRS were highly correlated with problematic gambling and video game dependence. ${ }^{8,9}$
The aim of our study is to examine the association of the fear of missing out with hyperactivity and impulsivity.

\section{MATERIALS AND METHODS}

Participants: Our Study was approved by the Uskudar University head of non-interventional ethics committee (Date: 03/07/2017, decision no: B.08.6.YÖK.ÜS.0.05.0.06/2017/175). This study was conducted under the Liberty project, which was carried out throughout Istanbul. Between July 2017 and October 2017, the participants were selected from various fields of study such as schools, municipal buildings, private companies, and public places such as neighborhood units, courses, and charities. After the introduction of the research, potential participants were asked whether they would like to participate in the study by explaining the purpose of the research. Individuals aged 18 and over, to be studying at university or graduating were included in the study. Following the signing of the informed volunteer form, the questionnaires which were included in the data collection tools were ensured to be filled by the participants based on the self-report of the participant under the supervision of the interviewer. Directives for scales are given both verbally and in writing. The clinical psychologists $(n=6)$ carried out the interviews in the study. Questions of the volunteers who asked for help during the application were answered. Filling the questionnaires took 45 minutes on average for each participant. The approval of the Ethics Committee of the study was taken from Üsküdar University Ethics Committee of Non-Invasive Researches. The sample of the study consisted of randomly selected 425 female and 307 male university students and graduates making a total of 732 individuals.

Measures: The scales in the study were administrated to the study participants by the investigator. The scales used in the study were The Sociodemographic Questionnaire, Adult Attention Deficit Hyperactivity Disorder Self-Report Scale (ASRS), The Barratt Impulsivity Scale (BIS-11), and Üsküdar Fomo Scale.

Sociodemographic Questionnaire: A sociodemographic questionnaire was administered to collect information about the study participants. This form includes questions about the gender, date of birth, weight, height, education, and the use of nicotine, substances or alcohol.

Adult Attention Deficit Hyperactivity Disorder SelfReport Scale (ASRS): It is one of the scales developed by the World Health Organization (WHO) to 
screen mental disorders ${ }^{10}$. The validity and reliability study of the Turkish version of the scale was conducted by Doğan et al. ${ }^{11}$. The higher scores indicate the presence of a relatively more severe psychopathology. The scale consists of 18 items and has two sub-dimensions. Nine items address attention deficits and the remaining nine items address the subdimension of hyperactivity/impulsivity. Questions have been developed to determine the frequency of emerging symptoms over the past six months. Responses to the questions in the scale are scored in a range from 0 to 4. "Never" is scored 0, "rarely" is scored 1, "sometimes" is scored 2, "often" is scored 3, and "very often" is scored $4 .^{12}$

The Barratt Impulsiveness Scale (BIS-11): The Barratt Impulsiveness Scale (BIS-11) is a self-report scale consisting of 30 items evaluating the construct of impulsivity. There are 3 sub-dimensions of the scale. These are Motor Impulsiveness (MI), NonPlanning (NP), and Attentional Impulsiveness (AI). The scale is assessed on a Likert scale ranking in a range from 1 to 4 .

"Rarely/never" is scored 1, "occasionally" is scored 2 , "often" is scored 3, and "almost always/always" is scored 4. The scale includes eight items evaluating attentional impulsiveness, 11 items evaluating motor impulsiveness, and 11 items evaluating nonplanning. A score of 4 indicates the highest level of impulsiveness. However, some items have been reversely scored to avoid the response bias and the responses are scored accordingly. ${ }^{13}$ The validity and reliability study of the Turkish version of the scale was conducted by Güleç et al. ${ }^{14}$

Üsküdar Fomo Scale: Üsküdar Fomo Scale was developed by Barış Metin, Ramazan Pehlivan and Nevzat Tarhan. The scale consists of 22 items. It is evaluated on a 5-point Likert scale. "I absolutely do not agree" is scored 1, "I do not agree" is scored 2, "I partly agree" is scored 3, "I agree" is scored 4, and "I absolutely agree" is scored 5 . The scale items 8 and 22 are scored reversely. ${ }^{15}$

Data Analysis: The data obtained in the study were analyzed using the IBM SPSS 24 program. Descriptive statistical methods were used to analyse the data and the assumptions of normal distribution were accepted to test the hypothesis. The Mann Whitney U test was used to determine the differences. Spearman correlation analyses and linear regression analysis were performed to determine the correlation levels between the scales and to examine the model, respectively. Statistical significance was set at $<0.05$ and all tests were two-tailed.

\section{RESULT}

Findings related to the socio-demographic characteristics and scale scores of the research group are presented.

In regard to the gender distribution of the participants in the survey; $425(58 \%)$ were females and 307 (42\%) were males. There were $440(60 \%)$ individuals with a mean age of 29 and 292 (40\%) individuals above 29 years of age. The number of the university graduates was $636(87 \%)$ and the number of individuals with postgraduate degrees was 96 (13\%). There were 258 (35\%) smokers and 474 nonsmokers in the study population (Table 1 ).

There was a weak correlation between the scores of attentional impulsiveness and Üsküdar Fomo Scales in the same/positive direction, significantly ( $\mathrm{r}=0.12$; $\mathrm{p}<0.01)$. There was a very weak correlation between the scores of motor impulsiveness and Üsküdar Fomo Scale in the same/positive direction significantly $(r=0.08, p<0.05)$. It was observed that there was not a significant correlation between the scores of non-planning and Üsküdar Fomo Scale ( $r=0.07$; $p>0.05)$. There was not a significant correlation between the scores of attention deficit and Üsküdar FOMO Scale $(\mathrm{r}=0.25, \mathrm{p}<0.001)$. There was not a significant correlation between the scores of hyperactivity/impulsivity and Üsküdar FOMO Scale $(\mathrm{r}=0.21, \mathrm{p}<0.001)$. There was not a significant correlation between the total scores of The Adult ADHD Self-Report Scale and the scores of The Üsküdar FOMO Scale $(\mathrm{r}=0.27, \mathrm{p}<0.001)$ (Table 2).

The comparison of The Üsküdar Fomo Scale scores by age, gender, and smoking status revealed that the scores were statistically significantly higher in the group of individuals under the age of 29 compared to the group of individuals who were 29 years and over $(\mathrm{p}<0.05)$ (Table 3).

The model developed to evaluate of the effect of scores of the Üsküdar Fomo Scale on the Barratt Impulsiveness Scale and The Adult ADHD SelfReport Scale subscales was found to be statistically significant $(\mathrm{F}=8.689 ; \mathrm{p}<0.05)$ (Table 4). According to the results of the analysis, the scores of the Üsküdar fomo scale were increased with Attention deficit $(\beta=0.0179 ; \quad p<0.5)$ and Hyperactivity/ Impulsivity $(\beta=0.0146 ; p<0.5)$, however, age decreased the scores of the Üsküdar fomo scale $(\beta=$ $0.090 ; \mathrm{p}<0.5)(\underline{\text { Table } 5})$.

\section{DISCUSSION AND CONCLUSION}

The present study aimed to investigate the effects of ADHD symptoms, impulsivity characteristics, 
smoking addiction, gender, and age of smoker and non-smoker university graduates. There are several studies available especially on the habits of social media use, ${ }^{16}$ life satisfaction, ${ }^{17}$ personal well-being and problematic internet use ${ }^{18}$ associated with the fear of missing out, which has gained a gradual increase in popularity in recent years.

The overall pattern of results shows that FoMO, $\mathrm{ADHD}$, and impulsiveness scores are not related according to gender and smoking status. ${ }^{19}$ FoMO doesn't depend on gender in the study on youths. ${ }^{5}$ On the other hand, In a study involving 218 participants who are adolescent, it was shown that female adolescents exhibited significantly higher degrees of smartphone dependence and smartphone influence. ${ }^{20}$ The fact that the studies have been done with adolescents and is a new concept may explain the inconsistency in the results. The study sample consisted of university students, resembling each other's social relations may have resulted in the lack of gender differences. For young people studying at the university, we can interpret social relationships in a way that is independent of gender and smoking. In the current period, fears that others are doing and that we are missing something can be considered as a problem that everyone should live in and even need to overcome. This may be the reason why gender and smoking relationships are not seen in FoMO in other behavioral dependencies such as the internet dependence ${ }^{21}$ and online game dependence. ${ }^{22}$

The correlation analysis performed to evaluate the data collected in present study demonstrated that the fear of missing out was associated both with ADHD and impulsiveness scores. Similarly the dependence on playing online games and internet dependence were associated with attention deficit ${ }^{23}$ and impulsiveness. ${ }^{24}$ It can be interpreted that the fear experienced is similar to the behavioral addiction characteristics in terms of personal characteristics.

A regression analysis was performed to assess the power of impact of the variables including age, gender, smoking status, attention deficit, and impulsivity traits in predicting the fear of missing out. The FoMO scores were significantly higher in the individuals below age 29 compared to those who were 29 or over and the same result was demonstrated in the regression analysis, too. The decreasing severity of the attention deficit symptoms with age ${ }^{25}$ may be interpreted in a way that it may decrease the intensity of the fear of missing out. At the same time, young people use social media relatively more than the elderly. It is notable that impulsiveness was not observed in the regression analysis unlike the other relationships observed in the correlation analysis. The association of the impulsiveness with the problematic internet use ${ }^{24}$ or with internet dependency ${ }^{26}$ have been shown in several studies. It is reported that individuals having characteristics of problematic internet use had introverted, obsessive, and inflexible traits more commonly compared to the individuals with more severe levels of fear of missing out. ${ }^{18}$ It is reported that individuals having extroverted personality traits at higher levels experience the fear of missing out more commonly. ${ }^{16}$

In conclusion; Symptoms of ADHD have become a growing problem in recent years. Several studies emphasize that there is a strong relationship between the attention deficit symptoms and emotional regulation skills. ${ }^{27}$ Current technological tools prevent people from establishing a balanced emotional process. Several behavioural dependencies keep people's minds busy by creating a network of anxiety and habitual behavioural patterns. Over time, the stressors experienced by the person cause the behaviour to occur more frequently by acting as triggers. People who develop the fear of missing out may also be prone to have difficulties in maintaining attention, and therefore, may tend to use the social media more commonly due to the stress experienced while trying to sustain attention. It may be suggested that the problem turns out to be a problem of discharging the tension during the efforts to sustain attention rather than being a mere curiosity about whether people experience joyful activities. Although the fear of missing out shows similarities in many aspects of internet dependency and the dependence on playing online games, it needs to be evaluated as a solution developed to establish emotional control.

The relationship between FoMO and attention deficit may create both an emotional compensation mechanism and a causal cycle. While the difficulty in attention may increase the use of social media, the use of social media may disrupt the long-term attention mechanism. These studies are very important in finding the sources of such relationships. Keeping track of the change in phone usage patterns over time can provide more useful information to understand the cause of disturbance in attention. Another suggestion is that examining social media usage habits after drug treatment of attention deficit can provide very meaningful results in the treatment of both attention deficit and social media use.

Ethics Committee Approval: Our Study was ap- 
proved by the Uskudar University head of noninterventional ethics committee (Date: 03/07/2017, decision no: B.08.6.YÖK.ÜS.0.05.0.06/2017/175).

Conflict of Interest: No conflict of interest was declared by the authors

Author Contributions: Concept-GHS; SupervisionGHS; Interpretation-GHS; Data Collection- HU; Processing- HU; Analysis and Interpretation- HU.

Peer-review: Externally peer-reviewed.

\section{REFERENCES}

1. Turkle, S. Alone together: Why we expect more from technology and less from each other. New York, Basic Books; 2010.

2. Brand M, Young KS, Laier C, Wölfling K, Potenza MN. Integrating psychological and neurobiological considerations regarding the development and maintenance of specific Internet-use disorders: An Interaction of Person-AffectCognition-Execution (I-PACE) model. Neurosci Biobehav Rev. 2016;71:252-266. doi:10.1016/ j.neubiorev.2016.08.033

3. Fox J, Moreland JJ. The dark side of social networking sites: An exploration of the relational and psychological stressors associated with Facebook use and affordances. Comput Human Behav. 2015;45:168-176.

4. Przybylski AK, Murayama K, Dehaan CR, Gladwell V. Motivational, emotional, and behavioral correlates of fear of missing out. Comput Human Behav. 2013;29(4):1841-1848.

5. Tomczyk Ł, Selmanagic-Lizde E. Fear of Missing Out (FOMO) among youth in Bosnia and Herzegovina - Scale and selected mechanisms. Child Youth Serv Rev. 2018;88:541-549.

6. Rosen LD, Whaling K, Rab S, Carrier LM. Is Facebook creating "iDisorders"? The link between clinical symptoms of psychiatric disorders and technology use, attitudes and anxiety. Comput Human Behav. 2013;29(3):1243-1254.

7. Klein RG, Mannuzza S, Olazagasti MAR, et al. Clinical and functional outcome of childhood attention-deficit/hyperactivity disorder 33 years later. Arch Gen Psychiatry. 2012;69(12):12951303. doi:10.1001/archgenpsychiatry.2012.271

8. Romo L, Rémond JJ, Kotbagi ACG, Plantey S, Kern L. Gambling and attention deficit hyperactivity disorders (ADHD) in adolescents. Psychotropes (Belgium). 2016;22(1):91-108.

9. Romo L, Rémond JJ, Coeffec A, et al. Gambling and Attention Deficit Hyperactivity Disorders
(ADHD) in a Population of French Students. J Gambl Stud. 2015;31(4):1261-1272. doi:10.1007/s10899-014-9515-9

10. Kessler RC, Berglund P, Demler O, Jin R, Merikangas KR, Walters EE. Lifetime prevalence and age-of-onset distributions of DSM-IV disorders in the National Comorbidity Survey Replication. Arch Gen Psychiatry. 2005;62(6):593-602. doi:10.1001/archpsyc.62.6.593

11. Doğan S, Öncü B, Varol Saraçoğlu G, Küçükgöncü S. Erişkin dikkat eksikliği hiperaktivite bozukluğu kendi bildirim ölçeği (ASRS-v1. 1): Türkçe formunun geçerlilik ve güvenilirliği. Anadolu Psikiyatri Dergisi. 2009;10(2):77-87.

12. Kessler RC, Adler LA, Gruber MJ, Sarawate CA, Spencer T, Van Brunt DL. Validity of the World Health Organization Adult ADHD SelfReport Scale (ASRS) Screener in a representative sample of health plan members. Int J Methods Psychiatr Res. 2007;16(2):52-65. doi: 10.1002/mpr.208

13. Patton JH, Stanford MS, Barratt ES. Factor structure of the Barratt impulsiveness scale. J Clin Psychol. 1995;51(6):768-774.

14. Güleç H, Tamam L, Turhan M, et al. Psychometric Properties of the Turkish Version of the Barratt Impulsiveness Scale-11. Klinik Psikofarmakoloji Bulteni. 2008;18(4).

15. Metin B, Pehlivan R, Tarhan N. Realiability and validity of Uskudar fear of missing out scale. JNBS. 2017;4(2):43-46. doi:10.5455/ JNBS. 1494334674

16. Blackwell D, Leaman C, Tramposch R, Osborne C, Liss M. Extraversion, neuroticism, attachment style and fear of missing out as predictors of social media use and addiction. April 2017:1-4.

17. Longstreet P, Brooks S. Life satisfaction: A key to managing internet \& social media addiction. Technol Soc. 2017;50:73-77.

18. Stead H, Bibby PA. Personality, fear of missing out and problematic internet use and their relationship to subjective well-being. Comput $\mathrm{Hu}-$ man Behav. 2017;76:534-540.

19. Toda M, Ezoe S, Mure K, Takeshita T. Relationship of smartphone dependence to general health status and personality traits among university students. Open J Prev Med. 2016;6(10):215-221.

20. Yang S-Y, Lin C-Y, Huang Y-C, Chang J-H. Gender differences in the association of smartphone use with the vitality and mental health of adolescent students. J Am Coll Health. 2018;66 
(7):693-701.

doi:10.1080/07448481.2018.1454930

21. Park S, Jeon HJ, Bae JN, Seong SJ, Hong JP. Prevalence and Psychiatric Comorbidities of Internet Addiction in a Nationwide Sample of Korean Adults. Psychiatry Investig. 2017;14 (6):879-882. doi:10.4306/pi.2017.14.6.879

22. Sussman CJ, Harper JM, Stahl JL, Weigle P. Internet and Video Game Addictions: Diagnosis, Epidemiology, and Neurobiology. Child Adolesc Psychiatr Clin N Am. 2018;27(2):307-326. doi:10.1016/j.chc.2017.11.015

23. Bılg1 B, Aksoy UM, Şahmelıkoğlu Onur Ö, Maner AF. Attention-deficit/hyperactivity disorder and nicotine dependence in adults. Noropsikiyatri Arsivi. 2017;54(4):322-327.

24. Criscitelli K, Avena NM. The neurobiological and behavioral overlaps of nicotine and food addiction. Prev Med. 2016;92:82-89. doi:10.1016/j.ypmed.2016.08.009

25. Goodman DW, Mitchell S, Rhodewalt L, Surman $\mathrm{CBH}$. Clinical presentation, piagnosis and treatment of attention-deficit hyperactivity disorder (ADHD) in older adults: A review of the evidence and its implications for clinical care. Drugs Aging. 2016;33(1):27-36. doi:10.1007/ s40266-015-0327-0

26. Li W, Zhang W, Xiao L, Nie J. The association of Internet addiction symptoms with impulsiveness, loneliness, novelty seeking and behavioral inhibition system among adults with attentiondeficit/hyperactivity disorder (ADHD). Psychiatry Res. 2016;243:357-364. doi:10.1016/ j.psychres.2016.02.020

27. Shaw P, Stringaris A, Nigg J, Leibenluft E. Emotion dysregulation in attention deficit hyperactivity disorder. Am J Psychiatry. 2014;171(3):276293. doi:10.1176/appi.ajp.2013.13070966 
Table 1. Distributions related to socio-demographic characteristics.

\begin{tabular}{|l|l|c|c|}
\hline $\mathbf{N}=\mathbf{7 3 2}$ & $\mathbf{n}$ & $\mathbf{\%}$ \\
\hline \multirow{3}{*}{ Gender } & Female & 425 & 58 \\
\cline { 2 - 4 } & Male & 307 & 42 \\
\hline \multirow{2}{*}{ Age } & Under age 29 & 440 & 60 \\
\cline { 2 - 4 } & Age 29 and over & 292 & 40 \\
\hline \multirow{2}{*}{ Educational Status } & University & 636 & 87 \\
\cline { 2 - 4 } & Post-graduate degree & 96 & 13 \\
\hline \multirow{2}{*}{ Smoking Status } & Yes & 258 & 35 \\
\cline { 2 - 4 } & No & 474 & 65 \\
\hline
\end{tabular}


Table 2. The Levels of correlation of the adult attention deficit hyperactivity disorder scale and its subdimensions with the Üsküdar fomo scale scores.

\begin{tabular}{|l|l|l|l|l|l|l|l|}
\hline \multirow{2}{*}{} & \multicolumn{2}{|l|}{ B=732 } & \multicolumn{2}{l|}{ ASRS } \\
\cline { 2 - 7 } & $\begin{array}{l}\text { Attentional } \\
\text { Impulsiveness }\end{array}$ & $\begin{array}{l}\text { Motor } \\
\text { Impulsiveness }\end{array}$ & $\begin{array}{l}\text { Non- } \\
\text { planning }\end{array}$ & $\begin{array}{l}\text { Attention } \\
\text { Deficit }\end{array}$ & $\begin{array}{l}\text { Hyperactivity } \\
\text { /Impulsivity }\end{array}$ & $\begin{array}{l}\text { ASRS Total } \\
\text { Score }\end{array}$ \\
\hline $\begin{array}{l}\text { Üsküdar } \\
\text { Fomo } \\
\text { Scale }\end{array}$ & $\mathrm{r}$ & 0.12 & 0.08 & 0.07 & 0.25 & 0.21 & 0.27 \\
\cline { 2 - 7 } & $\mathrm{p}$ & $0.002^{* *}$ & $0.026^{*}$ & 0.074 & $0.000^{* * *}$ & $0.000^{* * *}$ & $0.000^{* * *}$ \\
\hline
\end{tabular}

Spearman Correlation: ${ }^{*} p<0.05 * * p<0.01 * * * p<0.001$. 
Table 3. Comparison of the scores of the Üsküdar fomo scale in terms of gender, age, and smoking status.

\begin{tabular}{|c|c|c|c|c|c|c|c|}
\hline \multicolumn{2}{|l|}{$N=732$} & Variable & $\mathbf{n}$ & Mean & Order & $\mathbf{Z}$ & $\mathbf{P}$ \\
\hline \multirow{6}{*}{$\begin{array}{l}\text { Üsküdar } \\
\text { Fomo } \\
\text { Scale }\end{array}$} & \multirow{2}{*}{ By gender } & Female & 425 & 61.68 & 379.00 & \multirow{2}{*}{-1.882} & \multirow{2}{*}{0.060} \\
\hline & & Male & 307 & 59.53 & 349.20 & & \\
\hline & \multirow{2}{*}{ By Age } & Under age 29 & 440 & 62.29 & 384.83 & \multirow{2}{*}{-2.880} & \multirow{2}{*}{$0.004 *$} \\
\hline & & Age 29 and over & 292 & 58.50 & 338.88 & & \\
\hline & \multirow{2}{*}{$\begin{array}{ll}\text { According to } & \text { to } \\
\text { smoking status } & \end{array}$} & Yes & 258 & 59.96 & 354.13 & \multirow{2}{*}{-1.168} & \multirow{2}{*}{0.243} \\
\hline & & No & 474 & 61.23 & 373.23 & & \\
\hline
\end{tabular}

${ }_{p}<0.05 ; Z=$ Mann Whitney $U$ Test 
Table 4. The level of prediction of the Üsküdar fomo scale scores by variables.

\begin{tabular}{|c|c|c|c|}
\hline $\mathbf{R}$ & $\mathbf{R}^{\mathbf{2}}$ & Corrected $\mathbf{R}^{2}$ & Prediction Std. Error \\
\hline $0.296^{\mathrm{a}}$ & 0.088 & 0.078 & 14.908 \\
\hline
\end{tabular}


Table 5. Correlation coefficients and significance levels of the variables.

\begin{tabular}{|l|c|c|c|c|c|}
\hline Predictors & $\mathbf{B}$ & St Error & $\boldsymbol{\beta}$ & $\mathbf{t}$ & $\mathbf{p}$ \\
\hline Coefficient (a) & 55.371 & 4.791 & & 11.558 & .000 \\
\hline Attentional Impulsiveness & -0.119 & 0.210 & -0.030 & -0.567 & -0.571 \\
\hline Motor Impulsiveness & -0.013 & -0.160 & -0.004 & -0.082 & 0.935 \\
\hline Non Planning & -0.065 & 0.0146 & -0.019 & -0.445 & 0.657 \\
\hline Attention Deficit & 0.538 & 0.135 & 0.179 & 3.981 & 0.000 \\
\hline Hyperactivity / Impulsivity & 0.447 & 0.138 & 0.146 & 3.240 & 0.001 \\
\hline Age & -2.845 & 1.156 & -0.090 & -2.461 & 0.014 \\
\hline Gender & -1.992 & 1.137 & -0.063 & -1.752 & 0.080 \\
\hline Smoking Status & 1.050 & 1.173 & 0.032 & 0.896 & 0.371 \\
\hline
\end{tabular}

